\title{
Description and analysis of clinical pathways for oesophagogastric \\ adenocarcinoma, in 10 European countries (the EURECCA upper Gastro Intestinal Group - European Registration of Cancer Care)
}

\section{Version 21-09-2015}

\section{Authors}

M. Messager ${ }^{1,2}$, W. de Steur ${ }^{3}$, P.G. Boelens ${ }^{3}$, L.S. Jensen ${ }^{4}$, C. Mariette ${ }^{2}$, J. V. Reynolds ${ }^{5}$, J. Osorio ${ }^{6}$, M. Pera $^{6^{*}}$, J. Johansson ${ }^{7}$, P. Kołodziejczyk ${ }^{8}$, F. Roviello ${ }^{9}$, G. De Manzoni ${ }^{9}$, S.P. Mönig ${ }^{10}$, W. H. Allum ${ }^{1}$

The EURECCA upper GI group (European Registration of Cancer Care)

\section{Affiliations}

1. Department of Surgery, Royal Marsden NHS Foundation Trust, London, UK

2. Department of Digestive Surgery, Lille University Hospital, France

3. EURECCA, Department of Surgery, Leiden University Medical Centre, Leiden, the Netherlands

4. Department of Surgery Danish Oesophageal, GEJ and Gastric Cancer Group Att. University Laarhus, NBG, Denmark

5. Department of Surgery, St. James's Hospital, Dublin, Ireland

6. Department of Surgery, Hospital Mutua de Terrasa, and * Hospital Universitario del Mar. Institut Hospital del Mar d'Investigacions Mèdiques (IMIM), Barcelona, Spain

7. Department of Surgery, Lund University Hospital, Lund, Sweden

8. Department of Surgery, Jagiellonian University, Krakow, Poland

9. Italian Research Group for Gastric Cancer (GIRCG - ONLUS), Italy

10. Department of General, Visceral \& Cancer Surgery, University Hospital of Cologne, Germany

\section{Corresponding author}

W. H. Allum, Department of Surgery, Royal Marsden Hospital NHS Foundation Trust, London, United Kingdom

Email address: William.Allum@rmh.nhs.uk

Tel: +44(0) 2086613982 Fax: +44(0) 2079354444

\section{Key words}

EURECCA, oesophageal cancer, gastric cancer, clinical pathway, care pathway, national health policy

Word count

Abstract 247

Manuscript (including reference) 3256 


\section{KEY MESSAGE}

There are currently both similarities and variations in clinical pathways for oesophagogastric adenocarcinoma in Europe with respect to approaches for staging, multidisciplinary meetings, research, audit, and overall service provision. Standardisation and harmonization across Europe of clinical pathways may improve quality of care and patient's experience, but this will depend on service organization and availability of resources.

\section{ABSTRACT}

Aims:

Outcomes for patients with oesophago-gastric cancer are variable across Europe. The reasons for this variability are not clear. The aim of this study was to describe and analyse clinical pathways to understand differences in service provision for oesophageal and gastric cancer in the countries participating in the EURECCA Upper GI group.

Methods:

A questionnaire was devised to assess clinical presentation, diagnosis, staging, treatment, pathology, follow-up and service frameworks across Europe for patients with oesophageal and gastric cancer. The questionnaire was issued to experts from 14 countries. The responses were analysed quantitatively and qualitatively and compared.

Results:

The response rate was (10/14) $71.4 \%$. The approach to diagnosis was similar. Most countries established a diagnosis within 3 weeks of presentation. However, there were different approaches to staging with variable use of endoscopic ultrasound reflecting availability. There has been centralisation of treatments in most countries for oesophageal surgery. The most consistent area was the approach to pathology. There were variations in access to specialist nurse and dietitian support. Although most countries have multidisciplinary teams, their composition and frequency of meetings varied. The two main areas of significant difference were research and audit and overall service provision. Observations on service framework indicated that limited resources restricted many of the services.

Conclusion:

The principle approaches to diagnosis, treatment and pathology were similar. Factors affecting the quality of patient experience were variable. This may reflect availability of resources. Standard pathways of care may enhance both the quality of treatment and patient experience. 


\section{INTRODUCTION}

Despite improvement in multimodal strategies, overall survival for oesophageal and gastric cancer (OGC) remains poor across Europe. The EUROCARE-5 study reported an overall 5-year survival for stomach cancer of $25.1 \%$. Although there could have been evaluation bias, there were significant variations ranging from $16.0 \%$ in Denmark to $32.4 \%$ in Italy. The mean 5 -year survival for oesophageal cancer was $12.4 \%$ ranging from $8.9 \%$ in Denmark to $16.2 \%$ in Germany [1]. A detailed review of over 6000 patients treated in 5 countries has shown variation in the use of multimodal therapies, surgical approach, rates of complete resection, number of nodes retrieved and postoperative mortality rates [2]. The explanations for these variations and initiatives for improving outcomes are multifaceted. The EUROCARE data included countries with differing approaches to healthcare and there is limited comparative data on health service provision including the use of clinical pathways.

Clinical pathways are "structured multidisciplinary care plans that explicitly articulate the essential steps in treating specific clinical problems" [3]. The benefit of a clinical pathway is to organise care, optimising use of resources aiming for qualitative and quantitative improvements in outcome [4,5]. Specifically the patient's journey is defined from first appointment after initial symptoms to completion of treatment, often using national guidelines developed from evidencebased data in an attempt to standardise all aspects of care.

The aim of this study was to describe and analyse clinical pathways across Europe in order to understand differences in service provision for oesophageal and gastric cancer in the countries participating in the EURECCA Upper GI group $[2,6,7]$. 


\section{Materials and methods}

\section{QUESTIONNAIRE DESIGN}

A simple questionnaire was designed to assess different aspects of care (See complete questionnaire in appendix). This included patient presentation, diagnostic approaches, staging, multidisciplinary treatment planning, treatment strategy, pathology, follow-up and general comments. Responses were largely binary although there were both quantitative and qualitative answers. Only patients considered for curative treatment, including surgery, have been considered in the present study.

\section{CIRCULATION AND RESPONSE}

The questionnaire was circulated to representatives of the countries involved in the EURECCA Upper GI project. These individuals were identified in the context of their contribution to i) population based cohorts in their country, ii) national guidelines on oesophageal and gastric cancer, and iii) were opinion leaders of European scientific societies on oesophagogastric cancer. Respondents were asked to provide an overview of the service provision in their country rather than in their own departments using data from national and regional audits and registries as appropriate. It was acknowledged that clinical pathways may vary within countries and respondents used their knowledge of practice in their country, with internal controls to ensure concordance of the responses. Questionnaires were screened for evident errors with subsequent clarification asked as appropriate.

\section{DATA ANALYSIS}

Analysis of the returned questionnaires has been undertaken quantitatively and qualitatively but no formal statistical comparisons have been performed as this was designed as a comparative investigation. 


\section{RESULTS}

A total of 14 countries were invited to complete the questionnaire. Responses were received from Italy, Poland, Sweden, Ireland, The Netherlands, Spain, Germany, Denmark, France and UK (response rate $71.4 \%$ (10/14). All data from Spain were collected by the EURECCA Upper GI Group in Catalonia. There were no missing data in the questionnaires.

\section{PRESENTATION AND DIAGNOSIS}

In most countries (Table 1) patients present with symptoms to their family doctor although in Spain $40 \%$ present directly to a gastroenterologist (because he/she is present at the primary care centre); there are no screening programmes. Onward referral is usually to a gastroenterologist or endoscopist although initial referral is to a general or gastrointestinal surgeon (GI) in Ireland, Sweden, Italy and Poland. Referral for appointment in secondary care for endoscopy is usually between one and three weeks although it is less than one week in Denmark and more than three weeks in Poland and in The Netherlands. Diagnostic endoscopy is either performed by a gastroenterologist or by a GI surgeon at either diagnostic units or specialist centres in all countries (Table 1); in Italy the endoscopy is usually repeated in the centre. Histology of endoscopic biopsies is reported at diagnostic unit level but all review histology at the centres.

\section{STAGING}

Staging investigations are usually performed in the centres although in Ireland and the UK staging is done at both diagnostic and specialist centres and at diagnostic units in France. All regularly use computed tomography (CT). The delay for CT scanning is between one and three weeks except in Ireland (less than 1 week) and Poland (more than 3 weeks). For all locations (oesophageal, junctional and gastric), staging including interventional techniques is usually completed in 3 weeks although this takes longer in Germany, Italy and Poland. For all locations, EUS is less frequently used in 
Denmark, Sweden and Poland. PET-CT is rarely used in Germany and Poland. France and UK overall use most investigations with Poland using fewest.

\section{TREATMENT}

In all countries there were national guidelines for the treatment of OG cancer either in place or in development. In Denmark, Ireland, Spain and the UK there are national and / or regional government sponsored targets for care provision.

Multidisciplinary Team (MDT)

Multidisciplinary teams are in place in all countries (Table 2). All teams include core surgeon, medical and clinical oncologist with gastroenterologist / endoscopist except in Poland (Table 2). There is no specific pathology representation in the MDT in France and Poland. Allied health professionals (Nurse Specialist) are MDT members in Ireland, Sweden and UK with only the UK including a dietitian. Most MDTs meet weekly although in Denmark the meetings are twice weekly and in Poland monthly. In addition to the have specialist multidisciplinary meetings there are weekly diagnostic unit meetings in France, Germany, Sweden, and UK. The majority of cases $(75-100 \%)$ are discussed at MDTs except Italy (25-50\%) and Poland (0-25\%). The Polish respondent commented that MDTs are only occurring in a few expert centres.

Treatment

Following MDT discussion and the decision to treat, the time before treatment was usually one to three weeks although it was usually more than 3 weeks in France and Poland (Table 3). Patients are reviewed preoperatively in all specialist centres with dedicated cardiac and pulmonary assessment although there is no dedicated anaesthetic review during pre-assessment in Ireland. This includes nutritional assessment except in Germany, Italy and Poland.

Surgery is mainly performed in specialist centres in all countries, with access to Intensive Therapy Unit (ITU) /High Dependency Unit (HDU) infrastructures. In some countries, gastric resection 
is performed in the initial referral centre. Formalized Enhanced Recovery programmes (ERAS) are largely in place in some centres except France, The Netherlands, Germany, Spain and Poland. Endoscopic therapies including endoscopic mucosal resection are performed by specialist endoscopists in France, The Netherlands, Ireland, Italy and Spain, and by either specialist endoscopists or surgeons in the other countries.

All countries have surgical databases and audit is undertaken mandatorily in all countries except for France, Italy, Spain and Poland. Recruitment into clinical trials is variable with a median of $30 \%$ (range $10-80 \%$ ) of cases included in trials; Denmark has the highest recruitment rate. The availability of staff to support trial entry is the main reason for this variability.

\section{PATHOLOGY}

The approaches for pathology are the most consistent across the countries surveyed (Table 4). Histology reports are available following surgery within three weeks in all countries except Germany where reports are available in less than a week. The reports are all standardised including TNM stage and resection margins; all include response assessment to chemotherapy except Poland. Dissection of lymph nodes is variably performed: pathologist only in Spain; surgeon only in France, Germany and Italy; both pathologist and surgeon in The Netherlands, Denmark, Sweden and the UK. All have access to tumour banking except The Netherlands (within the next 2-4 years), Spain and Poland.

\section{FOLLOW-UP}

Follow-up policies showed expected differences across all nine countries. In Ireland, Spain, Poland and the UK patients are seen within 3 weeks of discharge following surgery; in all other countries the first appointment is after 3 weeks. Patients are subsequently seen six monthly in France, Italy, Poland and the UK with 3 monthly in all others. All countries undertake clinical review, which is supplemented by CT +/- tumour markers in France, The Netherlands, Germany, Italy and 
Spain; no country uses PET-CT for routine review. Most patients are seen in surgical clinics but also in oncology clinics in The Netherlands, Denmark, Ireland, the UK and Sweden (Table 5).

Recording of outcome data was commonly either within a local database or a regional registry. National registries were only present in 5 countries. In only 4 countries was data recording mandatory (The Netherlands, Denmark, Germany and UK).

\section{GENERAL COMMENTS}

All respondents were in favour of standardized clinical pathways, which they believe could be implemented where these were not currently in place. In addition there was consensus that adherence to pathways would improve patient outcomes. Further measures to improve outcome were recommended and include promoting both clinical trials and audit. There were specific examples of developing MDTs and more comprehensive approaches to diagnosis, which were described by Italy and Poland respectively. The major limitations to implementing standardized pathways reflected the approach to healthcare resourcing with 9 countries citing lack of financial support, 5 countries identified insufficient workforce capacity and 4 reported limited support from professional and specialty associations. This latter point appears to reflect a reluctance to embrace new approaches to care in the context of long standing service cultures. In only 3 countries were the economics of the service evaluated - Germany, Ireland and Sweden. 


\section{DISCUSSION}

The aim of the present study was to describe and analyze clinical pathways for patients undergoing curative treatment for oesophageal and gastric cancer in 10 different European countries involved in the EURECCA upper GI project. A questionnaire-based study such as this has its limitations reflecting the design of the questionnaire and the selection of the respondents who took part. There are therefore inevitable biases although the respondents were those who are closely involved with the management of oesophageal and gastric cancer in their countries and would be expected to have an accurate overview of the service. Moreover, internal and external controls might have limited the bias, as the responders were allowed to use national databases to guide their response, in order to gain accuracy.

Results showed both similarities and variations between the approaches practiced in those countries surveyed. Overall, there are similar approaches in patient assessment and diagnosis. Most countries are able to establish a diagnosis within 3 weeks of presentation. Endoscopy with confirmation by biopsy histology is the norm with no reliance on contrast radiology. There are variations with regard to the clinician who makes the initial assessment with variable access to primary or specialist diagnostic care. This reflects the individual healthcare systems across the 10 countries. Further investigation once a diagnosis is established does vary. All undertake crosssectional imaging with CT with emphasis on both assessment of metastasis but also $\mathrm{T}$ and $\mathrm{N}$ stage. In oesophageal cancer PET-CT is widely used in $75-100 \%$ of surgical patients. There was variable use of EUS reflecting availability and opinion that cross sectional and functional imaging provide sufficient accurate information. In gastric cancer both PET-CT and EUS showed considerable variation with widespread use in some countries and very little in others. The diagnostic role of PET-CT in gastric cancer still needs to be defined, however the present study reveals that despite the fact that its clinical value is still controversial, PET-CT is widely used. This partly reflects recommendations in different guidelines [8-12] and in countries without formal guidelines this reflects individual opinion. 
Surgical procedures were mainly performed in high volume, specialist centers with appropriate infrastructure including critical care. There are still some examples of gastrectomy being under taken in low volume units reflecting inclusion within general surgery services. Nevertheless, the evidence of improved outcomes following centralization of services described in different studies has occurred [13-15]. The preoperative assessment of patients is similar with dedicated cardiopulmonary review. Other initiatives such as Enhanced Recovery programs are variable in practice, possibly reflecting the relatively recent publication of guidelines for gastrectomy [16]. There was variation in a number of areas, which have been identified as improving quality of patient experience including MDT meetings, availability of nurse specialist support and dedicated dietitian and physiotherapist.

The two main areas of significant differences are in research and audit and overall service provision. Research and audit are resource intensive but are key factors in understanding practice and outcomes and for innovation for improvement. The importance of both of these areas raises the option of closer collaboration between countries, which can not only create a more comprehensive approach to data recording but also facilitate the timeliness of results from investigational studies. This is a specific aim of the EURECCA initiative. There were also significant differences in the overall approach to service provision. The role and functionality of multidisciplinary teams, the support of clinical nurse specialists and the provision of nutritional intervention by dietitians varied across all 10 countries. In addition, the observations on service framework indicated that limited resources restricted many of the services. It can be concluded that approaches to the management of oesophageal and gastric cancer are partly a reflection of the healthcare system and partly of the collaborative expertise within each country.

In 2010 Rotter et al. proposed an international definition of a clinical pathway as a structured multidisciplinary plan of action associated with 3 out of the 4 following criteria: i) aiming at translating guidelines or evidence to local structures, ii) comprising steps in a care plan, ii) defining 
these steps within a time frame or a progression, and iv) aiming to standardize care [17]. These approaches have been adopted in a number of countries. The delay between onset of symptoms and diagnostic endoscopy has been highlighted in the UK. Strategies to minimise this delay including specification of local diagnostic units and specialist treatment centres for oesophageal and gastric cancer has resulted in an increase in access to curative treatment as well as a decrease in operative mortality $[15,19]$. In Denmark centralization of gastric cancer surgery has resulted in improvements in the quality of care and a reduction in 30-day postoperative mortality [18]. In both Denmark and the UK these were government determined initiatives.

Clinical pathways have been associated with reduced health care costs such as by reducing length of inpatient stay. In a Cochrane meta-analysis including more than 11.000 patients treated in randomised controlled trials of clinical pathways, length of stay was reduced by 1.09 day $(95 \% \mathrm{Cl}$ 1.59-0.6) and in-hospital complication rate was significantly reduced ( $\mathrm{OR}=0.58,95 \% \mathrm{Cl} 0.36-0.94)$, with 1 complication being prevented for each 17 patients included in a clinical pathway [17]. Implementation of clinical pathways also contributes to improved communication and teamwork, optimizing management of resources [17]. This is of crucial importance as nearly $70 \%$ of medical errors are caused by lack of communication [4]. Rotter and colleagues concluded in their Cochrane review "The introduction of clinical pathways should be considered for diseases for which vast variation in treatment exists, drug costs are high and comprise a large portion of overall costs, and robust evidence for appropriate treatment is available". This statement is readily applicable to oesophageal and gastric cancer and is a strong argument in favour of the introduction of clinical pathways for these cancers across Europe not only in terms of patient outcome but also to facilitate service improvement in countries where resources are limited.

The present study has described those areas of practice, which are similar and those areas which are different across 10 European countries. In particular the areas of difference are those parts 
of the service which add quality to the patient experience. The underlying theme from the study is the need for further standardisation of services with due allowance for individual country variations in epidemiology. This could best be achieved by harmonising the clinical pathway for patients with oesophageal and gastric cancer and developing consistent guidelines for disease management. This will need appropriate resource and leadership both professionally and in service configuration which would be facilitated by common management guidelines. Further studies of the upper GI EURECCA program are intended to develop this approach.

\section{Acknowledgments}

The authors would like to thank all the participating countries and participants of the EURECCA upper GI group for their input and providing the results for this questionnaire.

\section{Conflict of interest}

The authors declare no conflict of interest.

\section{Funding}

The 2013 Annual Grant for international mobility from the AFC (French Association of Surgery) was part of the salary of MM. 


\section{Reference}

1. De Angelis R, Sant M, Coleman MP, et al; EUROCARE-5 Working Group. Cancer survival in Europe 1999-2007 by country and age: results of EUROCARE--5-a population-based study. Lancet Oncol. 2014;15:23-34.

2. Messager M, de Steur W, van Sandick J, et al.; The EURECCA upper GI group. Variations among 5 European Countries for Curative Treatment of Resectable Oesophageal and Gastric Cancer: a survey from the EURECCA Upper GI Group (European Registration of Cancer Care). Eur J Surg Oncol. 2015 in press.

3. Kreys ED, Koeller JM. Role of clinical pathways in health care provision: Focus on cancer treatment. Am J Health Syst Pharm. 2013;70:1081-5.

4. Deneckere S, Euwema M, Van Herck P, et al. Care pathways lead to better teamwork: results of a systematic review. Soc Sci Med. 2012;75:264-8.

5. Van Houdt S, Heyrman J, Vanhaecht K, et al. Care pathways across the primary-hospital care continuum: using the multi-level framework in explaining care coordination. BMC Health Serv Res. 2013;13:296-308.

6. de Steur WO, Henneman D, Allum WH, et al. Common data items in seven European oesophagogastric cancer surgery registries: towards a European upper GI cancer audit (EURECCA Upper GI). Eur J Surg Oncol. 2014;40:325-9.

7. European Registration of Cancer Care, 2013. Available from: www.canceraudit.eu/index. php?paginaid=5>.

8. Allum WH, Blazeby JM, Griffin SM, et al; Association of Upper Gastrointestinal Surgeons of Great Britain and Ireland, the British Society of Gastroenterology and the British Association of Surgical Oncology. Guidelines for the management of oesophageal and gastric cancer. Gut. 2011;60:1449-72.

9. Moenig SP, Meyer HJ, Allum WH, et al. Third international conference of the European Union Network of Excellence on gastric and esophagogastric junction cancer, Cologne, Germany, June 2012. Gastric Cancer. 2015;18:193-9.

10. Waddell T, Verheij M, Allum W, et al; European Society for Medical Oncology (ESMO); Gastric cancer: ESMO-ESSO-ESTRO clinical practice guidelines for diagnosis, treatment and follow-up. European Society of Surgical Oncology (ESSO); European Society of Radiotherapy and Oncology (ESTRO). Eur J Surg Oncol. 2014;40:584-91.

11. Stahl M, Mariette C, Haustermans K, et al; ESMO Guidelines Working Group. Oesophageal cancer: ESMO Clinical Practice Guidelines for diagnosis, treatment and follow-up. Ann Oncol. 2013;24:51-6.

12. Lutz MP, Zalcberg JR, Ducreux M, et al; First St Gallen EORTC Gastrointestinal Cancer Conference 2012 Expert Panel. Highlights of the EORTC St. Gallen International Expert Consensus on the primary therapy of gastric, gastroesophageal and oesophageal cancer - differential treatment strategies for subtypes of early gastroesophageal cancer. Eur J Cancer. 2012;48:2941-53.

13. Lordick F, Allum W, Carneiro F, et al. Unmet needs and challenges in gastric cancer: the way forward. Cancer Treat Rev. 2014;40:692-700. 
14. Wouters MW, Gooiker GA, van Sandick JW, et al. The volume-outcome relation in the surgical treatment of esophageal cancer: a systematic review and meta-analysis. Cancer. 2012;118:1754-63.

15. Groene O, Chadwick G, Riley S, et al. Re-organisation of oesophago-gastric cancer services in England and Wales: a follow-up assessment of progress and remaining challenges. BMC Res Notes. 2014;7:24-31.

16. Mortensen K, Nilsson M, Slim K, et al; Enhanced Recovery After Surgery (ERAS ${ }^{\circledR}$ ) Group. Consensus guidelines for enhanced recovery after gastrectomy: Enhanced Recovery After Surgery (ERAS ${ }^{\circledR}$ ) Society recommendations. Br J Surg. 2014;101:1209-29.

17. Rotter $T$, Kinsman L, James $E$ et al. Clinical pathways: effects on professional practice, patient outcomes, length of stay and hospital costs. Cochrane Database Syst Rev. 2010;3:CD006632.

18. Jensen LS, Nielsen $H$, Mortensen PB, et al. Enforcing centralization for gastric cancer in Denmark. Eur J Surg Oncol. 2010;361:50-4.

19. Palser TR, Cromwell DA, Hardwick RH, Riley et al. Re-organisation of oesophago-gastric cancer care in England: progress and remaining challenges. BMC Health Serv Res. 2009;9:204-12. 
Table I. $1^{\text {st }}$ symptoms: Patient experiencing signs of oesophago-gastric cancer, and diagnosis using endoscopy and biopsy

\begin{tabular}{|c|c|c|c|c|c|c|c|c|c|c|}
\hline Countries & \multirow{2}{*}{ Denmark } & \multirow{2}{*}{ France } & \multirow{2}{*}{$\begin{array}{l}\text { The } \\
\text { Netherlands }\end{array}$} & \multirow{2}{*}{ Germany } & \multirow{2}{*}{ Ireland } & \multirow{2}{*}{ Italy } & \multirow{2}{*}{ Spain } & \multirow{2}{*}{ Sweden } & \multirow{2}{*}{ Poland } & \multirow{2}{*}{ UK } \\
\hline Variables & & & & & & & & & & \\
\hline $\begin{array}{l}1^{\text {st }} \\
\text { appointment } \\
\text { performed by }\end{array}$ & $\begin{array}{l}90 \% \text { GP } \\
10 \% \text { End }\end{array}$ & $100 \%$ GP & $100 \%$ GP & $\begin{array}{l}80 \% \text { GP } \\
20 \% \text { GET }\end{array}$ & $100 \%$ GP & $80 \%$ GIS & $\begin{array}{c}60 \% \text { GP } \\
40 \% \text { GET }\end{array}$ & $\begin{array}{l}90 \% \mathrm{GP} \\
10 \% \mathrm{G}^{\mathrm{al}} \mathrm{S}\end{array}$ & $\begin{array}{l}80 \% \mathrm{GP} \\
10 \% \mathrm{GET} \\
10 \% \mathrm{G}^{\mathrm{al}} \mathrm{S}\end{array}$ & $100 \%$ GP \\
\hline $\begin{array}{l}1^{\text {st }} \text { specialist to } \\
\text { whom patient } \\
\text { is referred }\end{array}$ & $\begin{array}{l}100 \% \\
\text { End }\end{array}$ & $\begin{array}{l}90 \% \text { GET } \\
10 \% \text { End }\end{array}$ & $90 \%$ GET & $\begin{array}{c}90 \% \text { GET } \\
10 \% \text { GIS }\end{array}$ & $\begin{array}{l}70 \% \mathrm{G}^{\mathrm{al}} \mathrm{S} \\
30 \% \mathrm{GET} \\
<5 \% \text { Onc }\end{array}$ & $90 \%$ GIS & $\begin{array}{l}70 \% \text { GET } \\
20 \% \text { Onc } \\
10 \% \text { GIS }\end{array}$ & $\begin{array}{l}80 \% \mathrm{G}^{\mathrm{al}} \mathrm{S} \\
10 \% \mathrm{GET} \\
10 \% \mathrm{ENT}\end{array}$ & $\begin{array}{l}40 \% \mathrm{GET} \\
40 \% \mathrm{G}^{\mathrm{al}} \mathrm{S} \\
20 \% \text { Onc }\end{array}$ & $\begin{array}{l}80 \% \text { GET } \\
10 \% \mathrm{G}^{\mathrm{al} S} \\
10 \% \text { GIS }\end{array}$ \\
\hline $\begin{array}{l}\text { Delay (weeks) } \\
\text { to } 1^{\text {st }} \text { specialist } \\
\text { appointment }\end{array}$ & $<1$ & $1-3$ & $>3$ & $1-3$ & $1-3$ & $1-3$ & $1-3$ & $1-3$ & $>3$ & $1-3$ \\
\hline $\begin{array}{l}\text { Recommended } \\
\text { delay (weeks) } \\
\text { in country's } \\
\text { guidelines }\end{array}$ & $<1$ & No & $<1$ & No & $1-3^{*}$ & No & $1-3$ & No & No & $1-3^{f}$ \\
\hline $\begin{array}{l}\text { National } \\
\text { guidelines for } \\
\text { OG care } \\
\text { available }\end{array}$ & Yes & Yes & Yes & Yes & Ongoing & Yes & No & Ongoing ${ }^{\#}$ & Yes & Yes \\
\hline $\begin{array}{l}\text { Dedicated } \\
\text { information }\end{array}$ & Yes & Yes & Yes & Yes & Yes & No & No & Ongoing & Yes & Yes $^{\$}$ \\
\hline $\begin{array}{l}\text { Dedicated CNS } \\
\text { nurse }\end{array}$ & No & No & $\mathrm{No}^{€}$ & No & Yes & No & No & Ongoing & No & Yes \\
\hline $\begin{array}{l}\text { Delay (weeks) } \\
\text { to } 1^{\text {st }} \\
\text { endoscopy }\end{array}$ & $<1$ & $1-3$ & $1-3$ & $1-3$ & $1-3$ & $1-3$ & $1-3$ & $1-3$ & $>3$ & $1-3$ \\
\hline $\begin{array}{l}\text { Endoscopy } \\
\text { scheduled by }\end{array}$ & GP & GET & GP & GP & $\begin{array}{l}\text { GET } \\
\text { GIS }\end{array}$ & GIS & $\begin{array}{l}\text { GP } \\
\text { GET }\end{array}$ & $\begin{array}{l}\mathrm{GP} \\
\mathrm{G}^{\mathrm{al}} \mathrm{S}\end{array}$ & $\begin{array}{l}\text { GP } 40 \% \\
\text { GET 30\% } \\
\text { G }^{\text {al }} \text { S 30\% }\end{array}$ & $\begin{array}{c}\text { GP, GET } \\
\text { G }^{\text {al }} \text { S } \\
\text { GIS }\end{array}$ \\
\hline $\begin{array}{l}\text { Endoscopy } \\
\text { performed by }\end{array}$ & $\begin{array}{c}\text { GET } \\
\mathrm{G}^{\mathrm{al}} \mathrm{S}, \mathrm{GIS}\end{array}$ & GET & GET & GET & $\begin{array}{l}\text { GET } \\
\text { GIS }\end{array}$ & GET & GET & $\begin{array}{l}\text { GET } \\
G^{\text {al }} S\end{array}$ & $\begin{array}{l}\mathrm{G}^{\mathrm{al}} \mathrm{S} 60 \% \\
\text { GET } 40 \%\end{array}$ & $\begin{array}{c}\text { GET, } \text { G }^{\text {al }} \text { S } \\
\text { GIS }\end{array}$ \\
\hline $\begin{array}{l}\text { Histology } \\
\text { analyzed in a } \\
\text { district/local } \\
\text { hospital OR } \\
\text { specialist } \\
\text { centre }\end{array}$ & Both & Both & Both & District & Both & $\underset{* * *}{\text { District }}$ & Specialist & Both & Specialist & $\underset{\# \#}{\text { Both }}$ \\
\hline $\begin{array}{l}\mathrm{GP}=\mathrm{G}^{\text {al }} \text { practitione } \\
\mathrm{Gl}=\mathrm{G} \text { astro intestin } \\
{ }^{*} 10 \text { working days } \\
\text { \# In process via reg } \\
\mathrm{f}^{\mathrm{f}} 2 \text { weeks for urge } \\
\$ \text { There are also se } \\
{ }^{€} \text { In the Netherlan } \\
{ }^{* *} \text { Pathological an } \\
\text { \#\# Histology is ofte } \\
{ }^{* * *} \text { Often the endo }\end{array}$ & $\begin{array}{l}\text { GET=Gastro } \\
\text { OG=Oesog } \\
\text { r patients w } \\
\text { nal cancer c } \\
\text { suspected c } \\
\text { eral charitab } \\
\text {, all centraliz } \\
\text { sis is perfor } \\
\text { reviewed in } \\
\text { opy is repea }\end{array}$ & $\begin{array}{l}\text { nterologist, } \\
\text { tric, CNS=Ca } \\
\text { h a positive I } \\
\text { ntre networ } \\
\text { ncer } \\
\text { association } \\
\text { d centres m } \\
\text { ed in the pa } \\
\text { pecialist cen } \\
\text { ed in the spe }\end{array}$ & $\begin{array}{l}\mathrm{S}=\mathrm{G}^{\mathrm{al}} \text { Surgeon, } \\
\text { cer nurse specia } \\
\text { stology report } \\
\text { \& steering comn } \\
\text { that provide info } \\
\text { st have a case m } \\
\text { lological centre } \\
\text { e multi-disciplin } \\
\text { ialist centre }\end{array}$ & $\begin{array}{l}\text { nd=Endosco } \\
\text { st } \\
\text { ittee of natic } \\
\text { mation } \\
\text { nager } \\
\text { hich the GET } \\
\text { ry team, eve }\end{array}$ & $\begin{array}{l}\text { al Swedish o } \\
\text { S affiliated } \\
\text { for samples }\end{array}$ & $\begin{array}{l}\text { ality regist } \\
\text { oming fron }\end{array}$ & y for OG can & tals & nose throa & pecialist, \\
\hline
\end{tabular}




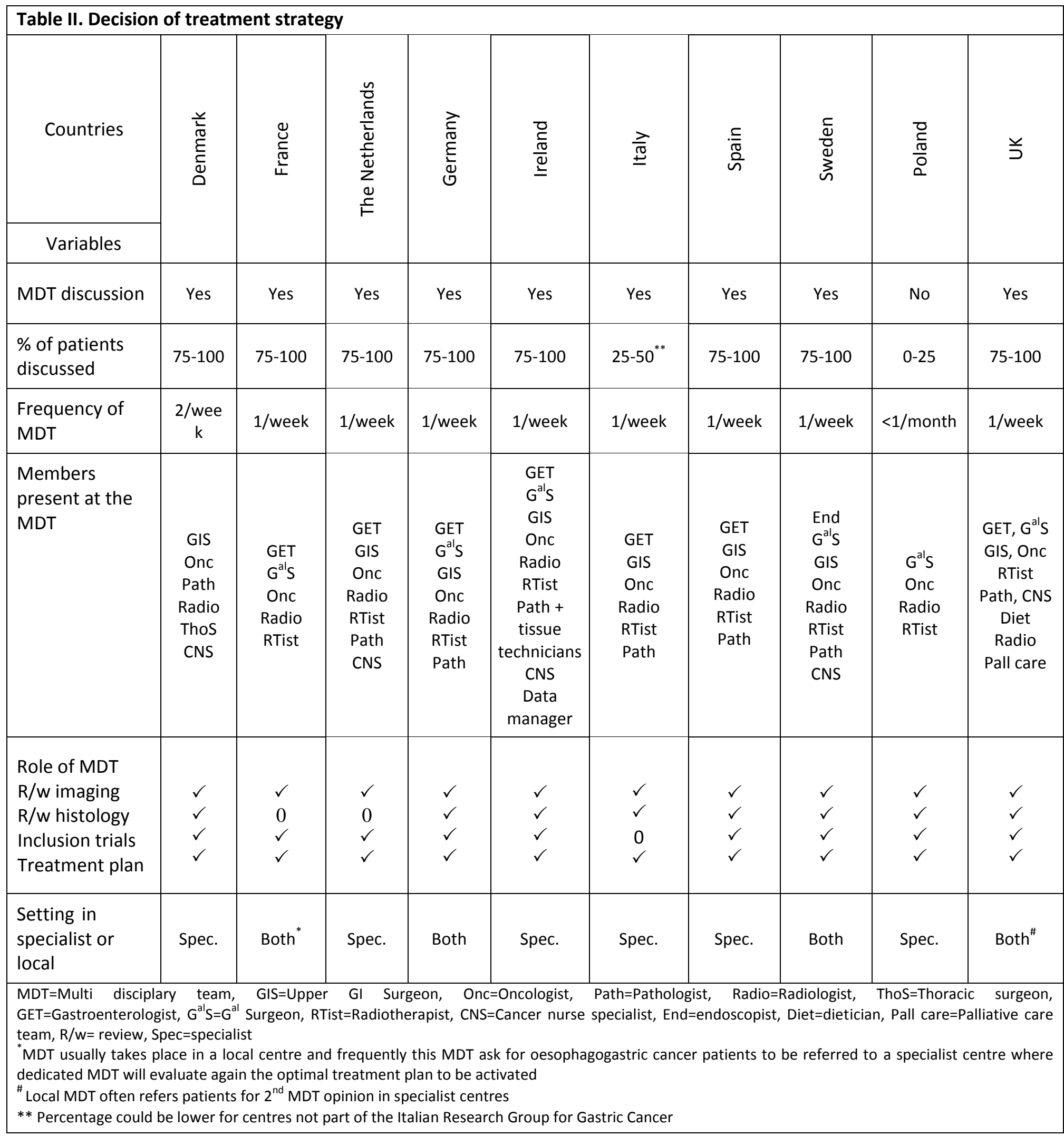




\begin{tabular}{|c|c|c|c|c|c|c|c|c|c|c|}
\hline \multicolumn{11}{|l|}{ Table III. Treatment } \\
\hline Countries & \multirow{2}{*}{$\begin{array}{c}\text { Denmar } \\
\mathrm{k}\end{array}$} & \multirow{2}{*}{ France } & \multirow{2}{*}{$\begin{array}{l}\text { The } \\
\text { Netherlands }\end{array}$} & \multirow{2}{*}{ Germany } & \multirow{2}{*}{ Ireland } & \multirow{2}{*}{ Italy } & \multirow{2}{*}{ Spain } & \multirow{2}{*}{ Sweden } & \multirow{2}{*}{ Poland } & \multirow{2}{*}{ UK } \\
\hline Variables & & & & & & & & & & \\
\hline $\begin{array}{l}\text { Delay (weeks) from } \\
\text { MDT }\end{array}$ & $1-3$ & $>3$ & $1-3$ & $1-3$ & $1-3$ & $1-3$ & $1-3$ & $1-3$ & $>3$ & $1-3$ \\
\hline $\begin{array}{l}\text { Pre-assmt performed } \\
\text { in district / specialist } \\
\text { centre }\end{array}$ & Spe & $\mathrm{Spe}^{*}$ & Spe & Both & Spe & Spe & Spe & Both & Spe & Both \\
\hline \multicolumn{11}{|l|}{ Pre-assmt involves } \\
\hline Cardiac tests & $\checkmark$ & $\checkmark$ & $\checkmark$ & $\checkmark$ & $\checkmark$ & $\checkmark$ & $\checkmark$ & $\checkmark$ & $\checkmark$ & $\checkmark$ \\
\hline Pulmonary tests & $\checkmark$ & $\checkmark$ & $\checkmark$ & $\checkmark$ & $\checkmark$ & $\checkmark$ & $\checkmark$ & $\checkmark$ & $\checkmark$ & $\checkmark$ \\
\hline Dietetic rw & $\checkmark$ & $\checkmark$ & $\checkmark$ & 0 & $\checkmark$ & 0 & $\checkmark$ & $\checkmark$ & 0 & $\checkmark$ \\
\hline Smoke \& OH rw & $\checkmark$ & Rarely & 0 & $\checkmark$ & $\checkmark$ & 0 & 0 & $\checkmark$ & 0 & $\checkmark$ \\
\hline Psychological rw & 0 & $\checkmark$ & 0 & 0 & $\checkmark$ & 0 & 0 & $\checkmark$ & 0 & $\checkmark$ \\
\hline Anaesth / ICU rw & $\checkmark$ & & $\checkmark$ & $\checkmark$ & 0 & $\checkmark$ & $\checkmark$ & $\checkmark$ & $\checkmark$ & $\checkmark$ \\
\hline $\begin{array}{l}\text { CT \& RT performed in } \\
\text { a } \\
\text { district/local centre }\end{array}$ & Spec. & Local & Spec. & Both & Spec. & Spec. & Spec. & Both & Spec. & Spec. \\
\hline $\begin{array}{l}\text { Surgery performed in } \\
\text { a } \\
\text { district / specialist } \\
\text { centre }\end{array}$ & Spec. & Spec. ${ }^{*}$ & Spec. & $\begin{array}{l}\text { Spec. or } \\
1^{\text {st }} \text { centre }\end{array}$ & Spec. & Spec. & Spec. & Spec. & Spec. ${ }^{*}$ & Spec. ${ }^{@}$ \\
\hline \multicolumn{11}{|l|}{ Surgical pathway } \\
\hline HDU & $\checkmark$ & $\checkmark$ & 0 & $\checkmark$ & $\checkmark$ & 0 & 0 & $\checkmark$ & $\checkmark$ & $\checkmark$ \\
\hline $\mathrm{ICU}$ & $\checkmark$ & $\checkmark$ & $\checkmark$ & $\checkmark$ & $\checkmark$ & $\checkmark$ & $\checkmark$ & $\checkmark$ & $\checkmark$ & $\checkmark$ \\
\hline ERAS program & $\checkmark$ & $0^{£}$ & 0 & 0 & $\checkmark$ & $\checkmark$ & 0 & $\checkmark$ & 0 & $\checkmark$ \\
\hline Postop audit & $\checkmark$ & $0^{\$}$ & $\checkmark$ & $\checkmark$ & $\checkmark$ & 0 & 0 & $\checkmark$ & 0 & $\checkmark$ \\
\hline Database & $\checkmark$ & $\checkmark$ & $\checkmark$ & $\checkmark$ & $\checkmark$ & $\checkmark$ & $\checkmark$ & $\checkmark$ & 0 & $\checkmark$ \\
\hline $\begin{array}{l}\text { EMR performed in/by } \\
\text { Specialist/local centre } \\
\text { Surgeon/endoscopist }\end{array}$ & $\begin{array}{l}\text { Spec. } \\
\text { ns }\end{array}$ & $\begin{array}{l}\text { Spec. } \\
\text { End }\end{array}$ & $\begin{array}{l}\text { Spec. } \\
\text { End }\end{array}$ & $\begin{array}{l}\text { Both } \\
\text { Surgeon }\end{array}$ & $\begin{array}{l}\text { Spec. } \\
\text { End }\end{array}$ & $\begin{array}{l}\text { Spec. } \\
\text { End }\end{array}$ & $\begin{array}{l}\text { Spec. } \\
\text { End }\end{array}$ & $\begin{array}{l}\text { Spec. } \\
\text { End + } \\
\text { Surgeon }\end{array}$ & $\begin{array}{l}\text { Spec. } \\
\text { ns }\end{array}$ & $\begin{array}{c}\text { Spec. } \\
\text { ns }\end{array}$ \\
\hline \multicolumn{11}{|l|}{ Additional support } \\
\hline Dedicated nurse & $\checkmark$ & & & & $\checkmark$ & 0 & 0 & $\checkmark$ & 0 & $\checkmark$ \\
\hline Nutritional team & $\checkmark$ & $\checkmark$ & $\checkmark$ & $\checkmark$ & $\checkmark$ & $\checkmark$ & $\checkmark$ & $\checkmark$ & 0 & $\checkmark$ \\
\hline Physiological team & 0 & $\checkmark$ & 0 & $\checkmark$ & $\checkmark$ & 0 & $\checkmark$ & $\checkmark$ & 0 & $\checkmark$ \\
\hline Training sessions & 0 & 0 & $\checkmark$ & $\checkmark$ & $\checkmark$ & 0 & 0 & 0 & 0 & $\checkmark$ \\
\hline Evaluation of costs & 0 & 0 & 0 & $\checkmark$ & 0 & 0 & 0 & $\checkmark$ & 0 & 0 \\
\hline \multirow{3}{*}{$\begin{array}{l}\text { Pts screened for CS } \\
\text { (\%) } \\
\text { Pts Included in CS (\%) } \\
\text { Units with CS staff (\%) }\end{array}$} & 90 & 10 & \multirow{3}{*}{$€$} & 90 & 100 & 80 & 20 & 70 & 40 & 100 \\
\hline & 80 & 10 & & 10 & 40 & 50 & 10 & 50 & 20 & 30 \\
\hline & 100 & $20^{\#}$ & & ns & 100 & 50 & 20 & 20 & 10 & $100^{* *}$ \\
\hline
\end{tabular}


MDT=Multi disciplinary team, wk= week, Pre-assmt=pre-assessment, rw=review, $\mathrm{OH}=$ alcohol, ICU=intensive care unit, $\mathrm{CT}=\mathrm{chemotherapy}$, $\mathrm{RT}=$ radiotherapy, $\mathrm{HDU}=$ high dependency unit, ICU=Intensive Care Unit, ERAS=enhance recovery after surgery, EMR=Endoscopic mucosal resection, $\mathrm{CS}=$ Clinical studies, End=Endoscopist, $\mathrm{ns}=$ non specified, $\mathrm{Spec}=$ specialist

"Most frequently but due to absence of any obligation of referring such patients, it can be done in non specialised centres

${ }^{\mathrm{f}}$ Except in very few centres of excellence

$\$$ No external audit formalised in France, just internal review of morbidity-mortality

\#Highly variable according to centres, with $100 \%$ of patients screened and $50 \%$ included in some very few high volume centres

* Except for gastric cancer, in this case surgery in the first centre consulted (and for some oesophageal cases too in France)

$@$ There is centralization of oesogastric procedures for cancer in centres with accreditation

${ }^{* *}$ There is a research cancer network available for each centre

${ }^{€}$ For the Netherlands, this is monitored at the Gastroenterologist. 


\begin{tabular}{|c|c|c|c|c|c|c|c|c|c|c|}
\hline Countries & \multirow{2}{*}{ Denmark } & \multirow{2}{*}{ France } & \multirow{2}{*}{$\begin{array}{l}\text { The } \\
\text { Netherlands }\end{array}$} & \multirow{2}{*}{ Germany } & \multirow{2}{*}{ Ireland } & \multirow{2}{*}{ Italy } & \multirow{2}{*}{ Spain } & \multirow{2}{*}{ Sweden } & \multirow{2}{*}{ Poland } & \multirow{2}{*}{ UK } \\
\hline Variables & & & & & & & & & & \\
\hline $\begin{array}{l}\text { Delay (weeks) to } \\
\text { get report }\end{array}$ & $1-3$ & $1-3$ & $1-3$ & $<1$ & $1-3$ & $1-3$ & $1-3$ & $1-3$ & $1-3$ & $1-3$ \\
\hline $\begin{array}{l}\text { Report description } \\
\text { Standardized } \\
\text { pTNM stage } \\
\text { Margins } \\
\text { Tumour response }\end{array}$ & $\begin{array}{l}\checkmark \\
\checkmark \\
\checkmark \\
\checkmark\end{array}$ & $\begin{array}{l}\checkmark \\
\checkmark \\
\checkmark \\
\checkmark\end{array}$ & $\begin{array}{l}\checkmark \\
\checkmark \\
\checkmark \\
\checkmark\end{array}$ & $\begin{array}{l}\checkmark \\
\checkmark \\
\checkmark \\
\checkmark\end{array}$ & $\begin{array}{l}\checkmark \\
\checkmark \\
\checkmark \\
\checkmark\end{array}$ & $\begin{array}{l}\checkmark \\
\checkmark \\
\checkmark \\
\checkmark\end{array}$ & $\begin{array}{l}\checkmark \\
\checkmark \\
\checkmark \\
\checkmark\end{array}$ & $\begin{array}{l}\checkmark \\
\checkmark \\
\checkmark \\
\checkmark\end{array}$ & $\begin{array}{l}\checkmark \\
\checkmark \\
\checkmark \\
0\end{array}$ & $\begin{array}{l}\checkmark^{*} \\
\checkmark \\
\checkmark \\
\checkmark\end{array}$ \\
\hline $\begin{array}{l}\text { Separate LN } \\
\text { dissection done by } \\
\text { surgeon or } \\
\text { pathologist }\end{array}$ & Both & Surgeon & No & Surgeon & No & Surgeon & Path & Both & Path & Both \\
\hline Tumour banking & Yes & Yes & $\mathrm{No}^{\$}$ & Yes & Yes & Yes & No & Yes & No & Yes \\
\hline $\begin{array}{l}\text { New MDT } \\
\text { discussion after } \\
\text { pathology report }\end{array}$ & No & Yes & No & Yes & Yes & No & Yes & Yes & No & Yes \\
\hline $\begin{array}{l}\mathrm{LN}=\mathrm{Lymph} \text { node, } \mathrm{MDT}=1 \\
{ }^{*} \mathrm{HER} 2 \text { assessment perfo } \\
\$ \text { For The Netherlands, t }\end{array}$ & $\begin{array}{l}\text { ti disciplinar } \\
\text { ed }\end{array}$ & $\begin{array}{l}\text { team, Path } \\
\text { vill be realize }\end{array}$ & $\begin{array}{l}\text { thologist } \\
\text { the next 2-4 yea }\end{array}$ & & & & & & & \\
\hline
\end{tabular}




\begin{tabular}{|c|c|c|c|c|c|c|c|c|c|c|}
\hline Countries & \multirow{2}{*}{ Denmark } & \multirow{2}{*}{ France } & \multirow{2}{*}{$\begin{array}{l}\text { The } \\
\text { Netherlands }\end{array}$} & \multirow{2}{*}{ Germany } & \multirow{2}{*}{ Ireland } & \multirow{2}{*}{ Italy } & \multirow{2}{*}{ Spain } & \multirow{2}{*}{ Sweden } & \multirow{2}{*}{ Poland } & \multirow{2}{*}{ UK } \\
\hline Variables & & & & & & & & & & \\
\hline $\begin{array}{l}\text { Delay to } 1^{\text {st }} \text { OPC } \\
\text { (weeks) }\end{array}$ & $>3$ & $>3$ & $1-3$ & $>3$ & $1-3$ & $>3$ & $1-3$ & $>3$ & $1-3$ & $1-3$ \\
\hline $\begin{array}{l}\text { Follow-up involved } \\
\text {-Clinical exam } \\
\text {-CT scan } \\
\text {-Tumour markers } \\
\text {-PET }\end{array}$ & $\begin{array}{l}\checkmark \\
0 \\
0 \\
0\end{array}$ & $\begin{array}{l}\checkmark \\
\checkmark \\
\checkmark^{*} \\
0\end{array}$ & $\begin{array}{l}\checkmark^{€} \\
0 \\
0 \\
0\end{array}$ & $\begin{array}{l}\checkmark \\
\checkmark \\
\checkmark \\
0\end{array}$ & $\begin{array}{l}\checkmark \\
0 \\
0 \\
0\end{array}$ & $\begin{array}{l}\checkmark \\
\checkmark \\
\checkmark \\
0\end{array}$ & $\begin{array}{l}\checkmark^{\#} \\
\checkmark \\
\checkmark \\
0\end{array}$ & $\begin{array}{l}\checkmark^{\$} \\
0 \\
0 \\
0\end{array}$ & $\begin{array}{l}\checkmark^{¥} \\
0 \\
0 \\
0\end{array}$ & $\begin{array}{c}\checkmark^{* *} \\
0 \\
0 \\
0\end{array}$ \\
\hline Frequency (months) & 3 & 6 & 3 & 3 & 3 & 6 & $3^{f}$ & 3 & 6 & 6 \\
\hline $\begin{array}{l}\text { Follow-up } \\
\text { performed by }\end{array}$ & GIS & $\begin{array}{l}\text { GET } \\
\text { Gals } \\
\text { Onc }\end{array}$ & $\begin{array}{c}\text { GIS } \\
\text { Onc } \\
\text { RTist }\end{array}$ & $\begin{array}{c}\text { GP, GET } \\
\mathrm{G}^{\mathrm{al}} \mathrm{S}, \mathrm{GIS} \\
\text { Onc, RTist }\end{array}$ & GIS & $\begin{array}{l}\mathrm{G}^{\mathrm{al} S} \\
\mathrm{GIS}\end{array}$ & $\begin{array}{l}\text { GIS } \\
\text { Onc }\end{array}$ & GIS & $\begin{array}{c}\text { GET } \\
\mathrm{G}^{\mathrm{al}} \mathrm{S}, \mathrm{GIS} \\
\text { Onc } \\
\text { RTist }\end{array}$ & $\begin{array}{l}\text { GIS } \\
\text { Onc } \\
\text { RTist }\end{array}$ \\
\hline $\begin{array}{l}\text { OPC=Out patient clinics, } \\
\text { Onc=Oncologist, GET=Gas } \\
{ }^{*} \text { Only for gastric cancers } \\
\text { ** Patients included in tria } \\
{ }^{ \pm} \text {During } 2 \text { years then ever }\end{array}$ & $\begin{array}{l}\mathrm{CT}=\text { Compute } \\
\text { oenterologist } \\
\text { And also Gast } \\
\text { may have re } \\
6 \text { months }{ }^{\epsilon} \mathrm{A}\end{array}$ & $\begin{array}{l}\text { tomogra } \\
\mathrm{G}^{\mathrm{al}} \mathrm{S}=\mathrm{G}^{\mathrm{al}} \mathrm{S} \\
\text { oscopy an } \\
\text { ular CT an } \\
\text { so depend }\end{array}$ & $\begin{array}{l}\text { hy, PET=Positron } \\
\text { rgeon, RTist=Radi } \\
\text { chest } X \text { ray }{ }^{\$} \text { And } \\
\text { tumour markers } \\
\text { on study protoco }\end{array}$ & $\begin{array}{l}\text { emission to } \\
\text { otherapist, En } \\
\text { endoscopy }{ }^{¥} A \\
\text { during follow- }\end{array}$ & $\begin{array}{l}\text { mography, } \\
d=\text { endosco } \\
\text { And ultraso } \\
\text { up }\end{array}$ & $\begin{array}{l}\mathrm{GP}=\mathrm{G} \\
\text { oist } \\
\text { and }\end{array}$ & & itioner, & $=$ Upper GI & urgeon, \\
\hline
\end{tabular}


Appendix: Blank questionnaire submitted to investigators (10 pages)

\section{Question 1: Patient presentation with symptoms}

a. Who does the patient see first? (Please tick what are the most common pathways according to the percentage of patients following this pathway)

\begin{tabular}{|l|l|l|l|l|l|l|l|l|l|l|l|}
\cline { 2 - 10 } \multicolumn{1}{c|}{} & $0 \%$ & $10 \%$ & $20 \%$ & $30 \%$ & $40 \%$ & $50 \%$ & $60 \%$ & $70 \%$ & $80 \%$ & $90 \%$ & $100 \%$ \\
\hline General Practitioner & & & & & & & & & & & \\
\hline Gastroenterologist & & & & & & & & & & & \\
\hline General Surgeon & & & & & & & & & & & \\
\hline Upper GI Surgeon & & & & & & & & & & & \\
\hline Oncologist & & & & & & & & & & & \\
\hline Radiotherapist & & & & & & & & & & & \\
\hline Other (Specify): & & & & & & & & & & & \\
\hline
\end{tabular}

b. To whom is the patient referred for investigation? (Please tick what are the most common pathways according to the percentage of patients following this pathway)

\begin{tabular}{|l|l|l|l|l|l|l|l|l|l|l|l|}
\cline { 2 - 10 } \multicolumn{1}{c|}{} & $0 \%$ & $10 \%$ & $20 \%$ & $30 \%$ & $40 \%$ & $50 \%$ & $60 \%$ & $70 \%$ & $80 \%$ & $90 \%$ & $100 \%$ \\
\hline General Practitioner & & & & & & & & & & & \\
\hline Gastroenterologist & & & & & & & & & & & \\
\hline General Surgeon & & & & & & & & & & & \\
\hline Upper GI Surgeon & & & & & & & & & & & \\
\hline Oncologist & & & & & & & & & & & \\
\hline Radiotherapist & & & & & & & & & & & \\
\hline Other (Specify): & & & & & & & & & & & \\
\hline
\end{tabular}

c. What is the time from decision to refer to appointment with specialist?
$\square<1$ week
$\square \quad 1-3$ weeks
$\square>3$ weeks

d. Is there a time specified in your country between decision to refer and appointment at hospital / clinic?
$\square$ Yes
$\square$ No
$\square$ Other (Specify):
$\square$ If yes:
$\square<1$ week
$\square$ 1-3 weeks
$\square>3$ weeks 
e. Additional National information: (Select one or more)

- Guidelines have been implemented in your country for O-G Cancer care?

$\square$ Yes

$\square$ No

$\square$ Other (Specify):

- Dedicated information for patients is available:

$\square$ Yes

$\square$ No

$\square$ Other (Specify):

- Dedicated Nurse Specialist support is available to all patients:

$\square$ Yes

$\square$ No

$\square$ Other (Specify):

\section{f. Box for comments:}


a. Waiting time from time of $1^{\text {st }}$ appointment to endoscopy:
$\square<1$ week
$\square$ 1-3 weeks
$\square>3$ weeks

b. Endoscopy is usually scheduled by:
$\square$ General Practitioner
$\square$ Gastroenterologist
$\square$ General Surgeon
$\square$ Upper GI Surgeon
$\square$ Oncologist
$\square$ Other (Specify):
$\square$ Different pathway (Specify):

c. Endoscopy is usually performed by:
$\square$ Gastroenterologist
$\square$ General Surgeon
$\square$ Upper GI Surgeon
$\square$ Oncologist
$\square$ Radiologist
$\square$ Other (Specify):
$\square$ Different pathway (Specify):

d. Histological analysis of the biopsy is performed:
$\square$ In a district hospital / a local clinical facility
$\square$ In a specialist centre or clinic
$\square$ Other (Specify):
$\square$ Different pathway (Specify):

e. Box for comments: 


\section{Once the diagnosis of cancer has been histologically confirmed:}

a. Where is the staging performed?
$\square \quad$ In a district setting
$\square \quad$ In a specialist setting
$\square \quad$ Other (Specify):
$\square \quad$ Different pathway (Specify):

b. What proportions of patients undergo the following investigations? (Tick the appropriate boxes)

\begin{tabular}{|c|c|c|c|c|c|c|c|c|c|c|c|c|}
\hline & \multicolumn{4}{|c|}{ Oesophagus } & \multicolumn{4}{|c|}{ Junction } & \multicolumn{4}{|c|}{ Stomach } \\
\hline & $\%$ & .•\% & $\cdots \%$ & $\cdots \% \%$ & •\% &..$\%$ & $\cdots \%$ & $\cdots \cdots \%$ & $\%$ & $.0 \%$ & $\cdots \%$ & $\cdots . . \%$ \\
\hline \multicolumn{13}{|l|}{ CT scan } \\
\hline \multicolumn{13}{|l|}{ EUS } \\
\hline \multicolumn{13}{|l|}{ Barium study } \\
\hline \multicolumn{13}{|l|}{ CT-PET scan } \\
\hline \multicolumn{13}{|l|}{ Laparoscopy } \\
\hline Other (Specify) & & & & & & & & & & & & \\
\hline
\end{tabular}

c. How long does it take for completion of staging?

i. Initial staging (CT Scan)
$\square<1$ week
$\square$ 1-3 weeks
$\square>3$ weeks

ii. Complete staging: EUS / PET scan / Laparoscopy
$\square<1$ week
$\square 1-3$ weeks
$\square>3$ weeks

c. Box for comments: 


\section{Question 4: Decision of treatment strategy}

a. Are patients' treatment plans discussed by a Specialist Multidisciplinary team
$\square$ Yes
$\square$ No

b. What is the proportion of patients that are discussed at a Multi Disciplinary Team (MDT) meeting for treatment planning?
$\square \quad 0-25 \%$
$\square \quad 25-50 \%$
$\square \quad 50-75 \%$
$\square \quad 75-100 \%$
$\square$ Different pathway (Specify):

c. What is the frequency of the MDT meeting?
$\square$ Weekly
$\square$ Twice a month
$\square$ Monthly
$\square$ Other (Specify):

d. Members of the MDT include: (Select one or more)
$\square$ Gastroenterologist / Endoscopist
$\square$ General Surgeon
$\square$ Upper GI Surgeon
$\square$ Oncologist
$\square$ Radiotherapist
$\square$ Pathologist
$\square$ Clinical Nurse Specialist
$\square$ Dietician
$\square$ Other (Specify):

e. What is processed during the MDT? (Select one or more)

$\square$ Review of morphological exams

$\square$ Review of histology

$\square$ Screening for inclusion in Clinical research / trial

$\square$ Other (Specify):

f. MDT takes place in what setting? (Select one or more)
$\square$ In a specialist centre
$\square$ In a local centre
$\square$ Other (Specify):
$\square$ Different pathway (Specify):

g. Box for comments: 


\section{Question 5: Treatment}

a. What is the delay from the MDT recommendation to the beginning of treatment?
$\square<1$ week
$\square \quad 1-3$ weeks
$\square>3$ weeks

b. Pre-therapeutic clinical assessment

i. Is performed in:

$\square$ A district setting

$\square$ A specialist centre (University / high volume centre)

$\square$ Other (Specify):

$\square$ Different pathway (Specify):

ii. Involves: (Select one or more)
$\square$ Cardiac tests
$\square$ Pulmonary tests
$\square$ Dietetic review
$\square$ Smoke and alcohol avoidance support
$\square$ Psychological support
$\square$ Anaesthetic / Intensivist review
$\square$ Other (Specify):

c. Oncology:

Chemotherapy and radiotherapy are mainly performed:

$\square$ In a specialist (university / high volume) centre

$\square$ In a local unit

$\square$ Other (Specify):

$\square$ Different pathway (Specify):

d. Surgery:

i. Is mainly performed:

$\square$ In a specialist (university / high volume) centre

$\square$ In the first centre consulted

$\square$ Other (Specify):

$\square$ Different pathway (Specify):

ii. Surgical care pathway: there is: (Select one or more)

$\square$ A high dependency unit available

$\square$ An Intensive Care Unit available

$\square$ An enhance recovery program proposed

$\square$ An audit of postoperative morbidity and mortality

$\square$ A prospective database for clinical studies 
iii. When indicated, therapeutic endoscopy is performed:
$\square$ In a specialist (university / high volume) centre
$\square$ In a local unit
$\square$ By the surgeon
$\square$ By a dedicated endoscopist
$\square$ Other (Specify):
$\square$ Different pathway (Specify):

iv. Additional support: (Select one or more)
$\square$ Dedicated nurse for treatment plan organization
$\square$ Presence of nutritional team support
$\square$ Presence of a dedicated physiological team
$\square$ Educational training sessions
$\square$ Evaluation of hospital stay costs

e. Clinical research in centres treating oesophago-gastric cancer: tick the appropriate boxes

\begin{tabular}{|l|l|l|l|l|l|l|l|l|l|l|l|}
\cline { 2 - 8 } \multicolumn{1}{l|}{} & $0 \%$ & $10 \%$ & $20 \%$ & $30 \%$ & $40 \%$ & $50 \%$ & $60 \%$ & $70 \%$ & $80 \%$ & $90 \%$ & $100 \%$ \\
\hline $\begin{array}{l}\text { \% of patients screened for inclusion in } \\
\text { clinical studies }\end{array}$ & & & & & & & & & & & \\
\hline \% of patients included in clinical studies & & & & & & & & & & & \\
\hline $\begin{array}{l}\text { \% of units with dedicated clinical study } \\
\text { department or staff }\end{array}$ & & & & & & & & & & & \\
\hline
\end{tabular}

f. Box for comments: 


\section{Question 6: Histological examination}

a. Interval from resection to histology report:
$\square<1$ week
$\square 1-3$ weeks
$\square>3$ weeks

b. Histological examination involves: (Select one or more)
$\square$ A dedicated standardized report
$\square$ A separate dissection of lymph nodes
$\square$ By the surgeon
$\square$ By the pathologist
$\square$ An assessment of pTNM stage
$\square$ An assessment of margin involvement
$\square$ An assessment of tumoral response when neoadjuvant treatment
$\square$ A new discussion in MDT
$\square$ Tumor banking
$\square$ Other (Specify):

d. Box for comments: 


\section{Question 7: Follow-up}

a. Interval from hospital discharge to first follow-up clinics:
$\square<1$ week
$\square$ 1-3 weeks
$\square>3$ weeks

b. Follow-up involves: (Select one or more)
$\square$ Clinical examination
$\square$ CT scan
$\square$ Measurement of serum tumour markers
$\square$ CT-PET
$\square$ Other (Specify):

c. Follow-up is performed approximately:
$\square$ Monthly
$\square$ Every 3 months
$\square$ Every 6 months
$\square$ Every 12 months
$\square$ Every 18 months
$\square$ Other (Specify):

d. Follow-up is performed by: (Select one or more)
$\square$ General Practitioner
$\square$ Gastroenterologist
$\square$ General Surgeon
$\square$ Upper GI Surgeon
$\square$ Oncologist
$\square$ Radiotherapist
$\square$ Other (Specify):
$\square$ Different pathway (Specify):

e. Box for comments: 


\section{Question 8: General opinion}

a. If not currently in place, do you think that a dedicated clinical care pathway in your country is feasible?
$\square$ Yes
$\square$ No
$\square$ Other (Specify):

b. Would you be in favour of a dedicated clinical care pathway in your department?
$\square$ Yes
$\square$ No
$\square$ Other (Specify):

c. Do you think such a pathway would improve patient outcomes?
$\square$ Yes
$\square$ No
$\square$ Other (Specify):

d. In general, what do you think would improve the outcome for patients in your country? (free text):

e. What would be the major limitation to implement clinical care pathway in your country?
$\square$ Financial reasons
$\square$ Lack of dedicated personal
$\square$ Lack of support from national scientific societies
$\square$ Other (Specify):

f. What facilities are available in your country for data recording (select one or more)?
$\square$ Local database / Registry
$\square$ Regional Registry
$\square$ National Registry

g. Is data recording voluntary or mandatory in your country?
$\square$ Voluntary
$\square$ Mandatory
$\square$ Other (Specify):

h. Box of comment: 